\title{
Characterization of didactic and pedagogical training in Brazilian stricto sensu Postgraduate Programs in Nursing*
}

\author{
Caracterização da formação didático-pedagógica em programas \\ brasileiros de pós-graduação stricto sensu em enfermagem \\ Caracterización de la formación didáctica pedagógica en programas \\ brasileños de posgrado stricto sensu en enfermería
}

How to cite this article:

Zamprogna KM, Backes VMS, Menegaz JC, Francisco BS. Characterization of didactic and pedagogical training in Brazilian stricto sensu Postgraduate Programs in Nursing. Rev Esc Enferm USP. 2019;53:e03430. DOI: http://dx.doi.org/10.1590/S1980-220X2017030503430

\section{Katheri Maris Zamprogna ${ }^{1}$ \\ Vânia Marli Schubert Backes ${ }^{1}$ \\ Jouhanna do Carmo Menegaz ${ }^{2}$ \\ Bruna de Souza Francisco ${ }^{1}$}

* Extracted from the disssertation: "Formação didático-pedagógica nos currículos de programas de pós-graduação em enfermagem”, Universidade Federal de Santa Catarina, 2015.

1 Universidade Federal de Santa

Catarina, Florianópolis, SC, Brazil.

2 Universidade Federal do Pará, Belém, PA, Brazil.
Corresponding author:

Katheri Maris Zamprogna

Rua Lauro Linhares, 970, B2,

203, Bairro Trindade

CEP 88036-002 - Florianópolis, SC, Brazil

katherizamprogna@gmail.com

\begin{abstract}
Objective: To characterize the didactic and pedagogical training offered in Brazilian stricto sensu Postgraduate Programs in Nursing. Method: Descriptive, documentary research, based on data from 30 postgraduate programs that offer an academic master's degree and a $\mathrm{PhD}$ degree. We collected the course projects and teaching plans of the disciplines related to didactic and pedagogical training, accessed through the Sucupira Platform or the institutional website. The variables were analyzed by descriptive statistics, through calculations of relative and absolute frequency. Results: Regarding the lines of research of the programs, it was evidenced that $17.4 \%(n=20)$ were related to didactic and pedagogical training, 9.4\% $(n=3)$ followed this approach and, regarding compulsory didactic and pedagogical disciplines, it was observed that they were expressed differently in the curricula of masters and $\mathrm{PhD}$ courses, since part of the masters courses $(56.6 \%$, $\mathrm{n}=17)$ and of the $\mathrm{PhD}$ courses $(76.6 \%, \mathrm{n}=23)$ did not have this requirement. Conclusion: There should be a Brazilian guideline to promote the didactic and pedagogical training of university professors.
\end{abstract}

\section{DESCRIPTORS}

Education, Nursing, Graduate; Education, Nursing; Education, Higher; Faculty. 


\section{INTRODUCTION}

During the development and expansion of higher education in Brazil, with the purpose of promoting technological, economic and social development, the postgraduate education was structured. The development of the country included not only organizing and expanding Higher Education Institutions (HEIs), but also training people to a high level of education ${ }^{(1)}$. For this reason, the regulation and definition of Brazilian postgraduate education was approved on Opinion 977/65 of the Federal Council of Education ${ }^{(2)}$.

The postgraduate education was divided in two types: lato sensu and stricto sensu. The first one focuses on specialization certificates, aiming to train professionals to act in the technical and service sector. The second is aimed at stimulating scientific research and delivering qualified training for professors, especially for higher education ${ }^{(1,3)}$. Therefore, stricto sensu education took up the role of training professor/ researchers for the HEIs, which are designed to train people and produce science.

As it was promoted by the government, stricto sensu education was, for many years, offered mainly by federal or state public HEIs. This scenario has been changing during the last decade, and currently $18.4 \%$ and $14.1 \%$ of masters and $\mathrm{PhD}$ courses, respectively, are held in private institutions ${ }^{(4)}$.

The first masters course in Nursing was offered in 1972, in the Southeast region ${ }^{(5)}$, and from then on they expanded to other regions. In May 2013, this field had 89 courses (28 $\mathrm{PhD}$ courses, 47 masters courses and 14 professional masters courses), and the Southeast region had the largest number (49.4\%), followed by Northeast (20.9\%), South (19.1\%), Central West (9\%) and North (2.3\%), which is still incipient in this area, showing a disparity in distribution throughout the country. The region with the highest increase of programs in the last decade was the Northeast. In general, postgraduate courses in nursing in public HEIs are mainly strictu sensu(6).

The expansion of postgraduate courses observed in the nursing area was a trend in all areas, with a considerable growth in the number of graduate programs in Brazil. According to the Center for Strategic Studies and Management (CGEE), from 1996 to 2014, the number of masters courses in Brazil increased from 1,187 to 3,620, and $\mathrm{PhD}$ courses increased from 630 to 1,954. Consequently, the graduates in the period corresponded to 50,026 and 16,729, respectively, with $379 \%$ and $486.2 \%$ increases in relation to the number of graduates in $1994^{(4)}$.

Based on the National Classification of Economic Activities (CNAE) (2014), the CGEE presents four fields of work for graduates: (1) manufacturing industry, (2) financial activities, insurance and related services, (3) professional, scientific and technical activities and (4) education, which corresponds to $41.1 \%$ of the total. If we consider the type of educational institution, we see that higher education is the sector that has contributed the most to the employment of graduates, with $91 \%$ of their total employment within this sector.
Considering these data and relating it to the fields of work available to nursing graduates, with special regard to higher education ${ }^{(7)}$, focused on the training of nurses in undergraduate courses, we ask: How is the didactic and pedagogical training offered in postgraduate programs in Nursing?

It is currently important to characterize the didactic and pedagogical training for four reasons: the evidence that most graduates will work in lecturing; the priority given by graduate programs to train researchers in detriment of professor; the characteristics of the scientific work process; and the need for programs to maintain production indices in the evaluation of research supporting agencies ${ }^{(3,8)}$.

The didactic and pedagogical training consisted of the curriculum adopted by the programs to provide training in teaching for these graduates. This structure can include the areas of concentration and lines of research related to professional training and/or training in lecturing and the technical or theoretical disciplines in nursing education. It is important to note that the option of researching the didactic and pedagogical training within the formal curriculum of the programs does not exclude the possibility of masters and $\mathrm{PhD}$ training developed through other extracurricular experiences, such as current or previous teaching experience, lato sensu specialization certificate, among others. Given the above, this study aimed to characterize the didactic and pedagogical training offered in Brazilian stricto sensu postgraduate programs in Nursing.

\section{METHOD}

\section{TYPE OF STUDY}

Descriptive and documentary research with quantitative approach ${ }^{(9)}$, conducted with 30 postgraduate programs in nursing. The design was chosen because it enables the recognition of the didactic and pedagogical project on the curriculum of the postgraduate programs, considering their organization in areas of concentration, lines of research and related disciplines.

\section{SAMPLE}

For the identification of the sample, we initially considered the Document of the Nursing Area ${ }^{(6)}$, which showed 63 courses/programs. In the data collection period, these data were compared with the records of the Plataforma Sucupira, which pointed out 66 courses/programs. To distinguish these two, we considered a program when the same HEI offered masters and $\mathrm{PhD}$ courses in Nursing. When only a masters or a $\mathrm{PhD}$ course was offered, it was considered as a course. Thus, the sample of this study consisted of 30 programs.

\section{Data collection}

The documentary data, course projects and teaching plans of the disciplines found in the course project and considered as didactic and pedagogical training were collected through the Plataforma Sucupira and institutional websites of the programs from February to June 2015, the data was collected 
through a standard form that contained the dichotomous variables, discrete quantitative variables, ordered qualitative variables and nominal qualitative variables of the study.

The variables region, areas of concentration, lines of research, number of disciplines related to didactic and pedagogical training and curricular project of the programs were collected in the Plataforma Sucupira. The websites of the programs were consulted to find the variables related to the type of educational institution, to verify which curriculum disciplines were compulsory and to determine the number of credit hours.

The areas of concentration, disciplines and lines of research were considered didactic/pedagogical when they presented the following terms and their variations: didactics, pedagogy, methodology, teaching, learning, teaching strategies, teaching approaches, education, curriculum, skills, teaching planning, education policies, education technologies, continued education.

\section{ANALYSIS OF DATA}

The variables were organized in spreadsheets in the software Microsoft Excel and analyzed by applying absolute and relative frequency calculations, using percentages and means to measure the variables and synthesize the data ${ }^{(9)}$.

\section{ETHICAL ASPECTS}

This manuscript is part of a master's dissertation and will present only some of the abovementioned variables. Given the type of methodological design chosen - documentary analysis of public documents - and considering that no human was involved in the research, the ethical precepts of the National Health Council Resolution 466/2012 were respected and there was no need of approval by the Research Ethics Committee with Human Beings.

\section{RESULTS}

Regarding the type of educational institution and region, of the 30 programs of the sample, $83.3 \%(n=25)$ were in federal public institutions, and $16.6 \%(n=5)$, in state public institutions. The North region was not included in the sample because it only offers masters courses in nursing. Regarding the other regions, $40 \%(n=12)$ of the programs were in the Southeast region; $23 \%(n=7)$, in the south; $23 \%$ $(n=7)$, in the Northeast; and 14\% $(n=4)$, in the Middle-West.

As for the variable area of concentration, 32 different areas were found. Considering the diversity of denominations, this qualitative variable was grouped into five thematic subgroups: Nursing and Care, which represented $31.3 \%(n=10)$ of the areas; Practice in Health and Nursing with 21.9\% ( $n=7)$; Nursing and the Social Context with $12.5 \%(n=4)$; and Education and Work in Health and Nursing with 9.4\% ( $n=3)$. Among these areas, $25 \%$ were classified as Other $(n=8)$, because they represented isolated themes. Among the programs that had areas related to education, two $(n=2)$ were in the South and one $(n=1)$, in the Northeast, respectively in the Universidade Federal de Santa Catarina, the Universidade Federal de Santa Maria and the Universidade Federal de Pernambuco.
As for the variable lines of research, it was found (Table 1$)$ that $17.4 \%$ of the programs $(n=20)$ had a relation with didactic and pedagogical training, mostly in the Southeast region, with $45 \%(n=9)$.

Table 1 - Characteristics of didactic and pedagogical lines of research in Brazilian stricto sensu Postgraduate Programs in Nursing - Brazil, 2015.

\begin{tabular}{lc}
\hline Total Lines of Research in the Programs & Frequency $(\%)$ \\
115 & 100.0 \\
\hline Regional Distribution of Didactic and Pedagogical Lines of Research \\
Southeast & 45.0 \\
South & 30.0 \\
Northeast & 20.0 \\
Center-West & 5.0 \\
North & 0.0 \\
\hline Number of Lines of Research in the Programs & \\
2 to 3 & 56.7 \\
4 to 5 & 30.0 \\
6 to 7 & 3.3 \\
9 to 10 & 10.0 \\
\hline Total of Didactic and Pedagogical Lines of Research in the Programs \\
20
\end{tabular}

Regarding the number of compulsory and optional didactic and pedagogical curriculum disciplines, Table 2 shows that the didactic and pedagogical training is expressed in a different way in masters and $\mathrm{PhD}$ courses, and is still not very expressive considering the total of disciplines.

Table 2 - Curriculum characteristics of the didactic and pedagogical disciplines of the Masters and PhD Programs included in the Brazilian stricto sensu Postgraduate Programs in Nursing - Brazil, 2015.

\begin{tabular}{|c|c|c|}
\hline Curriculum disciplines & Masters no. (\%) & PhD no. (\%) \\
\hline$\leq 13$ & $2(7.0)$ & $2(7.0)$ \\
\hline 14 to 24 & $11(37.0)$ & $8(27.0)$ \\
\hline 25 to 35 & $12(40.0)$ & $13(43.0)$ \\
\hline 36 to 46 & $2(7.0)$ & $4(13.0)$ \\
\hline 47 to 57 & $1(0.3)$ & $1(0.3)$ \\
\hline$\geq 60$ & $2(7.0)$ & $2(7.0)$ \\
\hline \multicolumn{3}{|c|}{ Didactic and pedagogical theoretical disciplines } \\
\hline 0 & $0(0.0)$ & $4(13.3)$ \\
\hline 1 & $14(46.6)$ & $8(26.7)$ \\
\hline 2 & $9(30.0)$ & $10(33.3)$ \\
\hline 3 & $2(6.6)$ & $3(10.0)$ \\
\hline 4 & $3(10.0)$ & $3(10.0)$ \\
\hline$\geq 6$ & $2(6.6)$ & $2(6.6)$ \\
\hline \multicolumn{3}{|c|}{ Optional didactic and pedagogical disciplines } \\
\hline 0 & $12(40.0)$ & $9(30)$ \\
\hline 1 & $5(16.6)$ & $10(33.3)$ \\
\hline 2 & $3(26.6)$ & $4(13.3)$ \\
\hline 3 & $3(10.0)$ & 5 (16.6) \\
\hline$\geq 5$ & $2(6.6)$ & $2(6.6)$ \\
\hline \multicolumn{3}{|c|}{ Compulsory didactic and pedagogical disciplines } \\
\hline 0 & 17 (56.6) & $23(76.6)$ \\
\hline 1 & $11(36.6)$ & 5 (16.6) \\
\hline 2 & $2(6.6)$ & $2(6.6)$ \\
\hline
\end{tabular}


As for the variable's distribution of credit hours and compulsory credits, it is observed that some masters courses did not have this requirement, as well as part of the $\mathrm{PhD}$ courses. Although all masters courses in the sample included didactic pedagogical disciplines, more than half of them, 56.6\% $(n=17)$, did not define compulsory credits corresponding to these disciplines. In $\mathrm{PhD}$ courses, this number rises to $76.6 \%$ $(\mathrm{n}=23)$, according to Table 3 .

Table 3 - Distribution of credit hours referring to the curricular subjects of the Brazilian stricto sensu Postgraduate Programs in Nursing - Brazil, 2015.

\begin{tabular}{lc}
\hline Compulsory credits in Masters courses & No. $(\%)$ \\
\hline 0 & $9(20.0)$ \\
3 to 5 & $2(6.0)$ \\
6 to 8 & $4(13.3)$ \\
9 to 11 & $2(6.6)$ \\
12 to 14 & $4(13.3)$ \\
15 to 17 & $4(13.3)$ \\
$\geq 18$ & $5(16.6)$ \\
\hline
\end{tabular}

Compulsory credits in $\mathrm{PhD}$ courses

0

8 (26.6)

1 to 10

4 (13.3)

11 to 20

9 (30.0)

21 to 30

3 (10.0)

31 to 40

2 (6.7)

$\geq 41$

3 (10.0)

Credits in Didactic and Pedagogical Disciplines/Compulsory - Masters

0

17 (56.6)

2

2 (6.6)

4 (13.3)

5 (16.6)

$\geq 5$

2 (6.6)

Credits in Didactic and Pedagogical Disciplines/Compulsory - PhD

0

$23(76.6)$

2

$1(3.3)$

2 (6.6)

$2(6.6)$

\section{DISCUSSION}

The induced growth in the number of postgraduate programs and the qualification of masters and $\mathrm{PhD}$ courses is a strategy adopted not only by Brazil to promote development and improve the quality of education ${ }^{(10)}$. There is a consensus that development is partially linked to the training of highly educated personnel capable of producing useful scientific knowledge related to national issues, such as the challenges presented in the National Postgraduate Plan 2011$2020^{(11)}$, which include public safety, energy, oil and natural gas, health, among others, and the $\mathrm{PhD}$ is the modality of higher education that would better prepare people to help the country deal with the problems of each of these areas.
Regarding the quality of training, there are several influential factors, including the regulation of higher education, the curriculum, the structure of schools and the pedagogical training of professors. On this last aspect, which is related to the topic of interest of this study, recent studies observed in the literature point out to the relevance and even the necessity for didactic and pedagogical training of nursing faculty $^{(12)}$. It is assumed that the professor learns throughout their life, and the teaching practice itself is experience, an important aspect to the development of pedagogical ability. However, as the constant discussion regarding the training of undergraduate nursing students and nursing staff in different services, the training of nursing teachers in the stricto sensu modality, considered here in its curricular components, is also worth discussing.

The nursing category is already considering the discussion on didactic and pedagogical training; however, there is no consensus on the degree of qualification that professors should reach or in what modality and in what way didactic and pedagogical training will be offered. Some authors ${ }^{(13)}$ understand that professors should have a $\mathrm{PhD}$ degree. However, a study ${ }^{(14)}$ points out that $\mathrm{PhD}$ holders who work as professors had at least one, but at most two disciplines in their training process that enabled them to practice teaching, most of them elective and attended by the student's own choice, something similar to the results of this study regarding curriculum offer.

The term "naturalization of the teaching practice"(15) is used to emphasize that, in the area of health, it is commonly understood that professional competence is equivalent to pedagogical competence. And, in the case of postgraduate education, it may be pertinent to say that, in addition to this assumption, it is also commonly understood that the scientific competence attested by a diploma in stricto sensu courses is equivalent to pedagogical competence. However, we are not affirming the primacy of formal curriculum teaching to the detriment of the contribution that previous or even extracurricular experiences provide.

Thus, there is a number of sources of knowledge necessary for teaching, which could be offered in postgraduate programs in a more expressive way, such as specialized pedagogical literature, legislation and educational context Considering that, according to a study ${ }^{(4)}$, a good part of the graduates tends to work as professors, it seems that the programs and the training are responsible for offering incentive and opportunities for reflection, and, in this aspect, the design of the curriculum can be a counterpoint.

In Brazil, the Parecer Sucupira ${ }^{(2)}$ aimed to meet the demands of the Ministry of Education and Culture, training professors, stimulating research in the country and training technicians and intellectual workers, possibly for working in the universities, in the executive power or in the private sector. However, the absorption of graduates has always been higher in universities than in any other sector, and the Brazilian universities are structured to secure the tripod teaching, research, outreach. The graduates would not only produce research, but would also train their peers, thus 
demanding curriculum designs that incorporate didactic and pedagogical training.

The postgraduate system considers the masters and $\mathrm{PhD}$ as two levels that are hierarchical; however, the masters degree is not necessarily a condition for joining or obtaining a $\mathrm{PhD}$ degree ${ }^{(2)}$. There is a tacit assumption that the modality that provides pedagogical training for the professor is the masters course, while the $\mathrm{PhD}$ course trains research$\mathrm{ers}^{(7)}$. This could explain the greater presence of didactic and pedagogical disciplines in the master's courses and the small presence of didactic and pedagogical training in the curriculum of $\mathrm{PhDs}$.

However, the design of the system admits $\mathrm{PhDs}$ without a master's degree. The results of this study demonstrate that not every masters student invests in the area related to didactic and pedagogical training, in lines of research and disciplines that can support teaching training. Therefore, it is necessary to consider that, if we assume the presence of didactic and pedagogical training, we associate the existence of such training with stricto sensu degrees; however, until now, there was no real knowledge of the scenario of nursing programs in this regard.

With the significant increase in the number of graduates ${ }^{(4,6)}$ and the requirement of a $\mathrm{PhD}$ degree to enter the career in any federal university professor, with the exception of countryside campuses or in the absence of $\mathrm{PhDs}$ to fill a position, it is relevant to reflect on the organization in areas, lines and disciplines in the postgraduate programs and on the offer of disciplines related to didactic and pedagogical training.

Since the lines of research derive from the areas of concentration and, in general, the compulsory and elective disciplines are structured and offered based on the lines of research, the issue of didactic and pedagogical training in nursing seems to be more focused on the field of research than on teaching in the courses offered and studied by future masters and $\mathrm{PhDs}$ in nursing.

About the lines of research, a related topic that was not explored in this study is the organization of research groups that, within the programs, work on these lines. Two studies corroborate the results presented here. The first one $\mathrm{e}^{(16)}$ corroborates the finding that the areas of concentration of the programs are mostly related to nursing and care issues, when it points out that $55.4 \%$ of the groups registered in the $\mathrm{CNPq}$ Directory of Research Groups have lines of research related to nursing care and specialties.

The second study ${ }^{(17)}$ corroborates the finding that most of the lines of research related to didactic and pedagogical training are located in the Southeast region, which may be related to the fact that this is one of the most prominent regions regarding the number of research groups in nursing education $^{(18)}$. The authors point to 12 research groups in education in the state of São Paulo, corresponding to 23.5\% of the research groups in education in Brazil ${ }^{(17)}$.

It is relevant to point out that the presence of investigations related to the area of didactic and pedagogical training indicates the interest of the category in the subject, but does not mean preparation for teaching by itself, since the teaching work process is different from the research work process. For a didactic and pedagogical training directed at teaching to occur, it is necessary to provide basic knowledge different from the knowledge required by research, such as pedagogical knowledge on content, knowledge on the curriculum and knowledge about students and their characteristics ${ }^{(19)}$.

Without a pedagogical training, the practice of the professor in higher education tends to be based on and to reproduce the experiences with professors considered good in their formation ${ }^{(20)}$. The absence of a training that enables an understanding of the role of the professor also contributes to the use of pedagogical models that may be incompatible with current curricular guidelines for nurses' education, as well as with the context and the health needs ${ }^{(20)}$.

Theoretical and practical disciplines are also necessary, since teaching practice is sometimes limited to the teaching internship. CAPES regulations ${ }^{(21)}$ must also be considered; they state that postgraduate programs would have to offer these disciplines only in the $\mathrm{PhD}$ course, in two semesters, and that in some programs this is a compulsory subject only for students with a postgraduate scholarship.

Even with the possibility that masters and $\mathrm{PhD}$ students have developed other extracurricular actions that enable them to exercise teaching or accumulate other sources of knowledge that support their teaching, it is necessary to consider that the transition to a nursing professor is a complex process, given the competencies and skills required by this activity ${ }^{(22)}$. Beyond institutional bureaucracy, current pedagogical requirements also require nurses to prepare not only for teaching practice, but also to deal with institutional contexts ${ }^{(22)}$, which, depending on configuration, will require the development of teaching, research and outreach, for example ${ }^{(23)}$.

\section{CONCLUSION}

The panorama of Brazilian stricto sensu postgraduate courses in nursing indicate an asymmetric distribution of programs throughout the country. The Southeast region has the largest number of programs, followed by South and Northeast. In the Middle-West region, there is incentive and this level of education is present; however, it is the region with the smaller number of programs. The North region offers only masters courses.

In this scenario, the courses are developed based on the lines of research and areas of concentration that represent the themes and scientific areas in which students' study and develop their activities. The results showed some areas of concentration related to the theme of nursing education, which were concentrated in two Brazilian regions. In this sense, the programs must work with the lines of research related to didactic and pedagogical training, since, despite their low number, the portion destined to this scientific production is significant.

It was found that the masters courses presented disciplines related to didactic and pedagogical training in their curriculum. However, this training was not compulsory to all students, and, even for the students with this 
requirement, the number of credit hours of this training was small compared to the compulsory load requested in most master's courses.

In $\mathrm{PhD}$ courses, the numbers reveal the existence of some courses without didactic and pedagogical theoretical disciplines. It is up to the students, their research line, area of concentration and the norms of development and organization of the program to take these optional disciplines or not.

This panorama demonstrates that there is no harmonization or implementation regarding the practices aimed at training the higher education professor in the Brazilian Nursing Postgraduate Programs. Thus, university pedagogy in nursing is open for professors with varied identities, depending on the individual training of each one. Therefore, it is necessary to re-evaluate the role of the postgraduate course, proposing guidelines according to the national curricular guidelines and health policies that institutionalize, in this modality of education, the training of the university professor, in order to provide quality teaching.

\section{RESUMO}

Objetivo: Caracterizar a formação didático-pedagógica ofertada em programas brasileiros de pós-graduação stricto sensu em Enfermagem. Método: Pesquisa descritiva, documental, realizada a partir dos dados de 30 programas de pós-graduação que ofertam curso de mestrado acadêmico e doutorado. Foram coletados os projetos de curso e planos de ensino das disciplinas relacionadas à formação didático-pedagógica, acessados via Plataforma Sucupira ou site institucional. A análise das variáveis ocorreu por estatística descritiva, por meio de cálculos de frequência relativa e absoluta. Resultados: Quanto às linhas de pesquisa dos programas, evidenciouse que $17,4 \%(n=20)$ tinham relação com a formação didático-pedagógica, já no que tange às áreas de concentração, 9,4\% ( $n=3)$ foram as que contemplaram esse enfoque, e em relação às disciplinas didático-pedagógicas obrigatórias, observou-se que se expressam de maneira distinta nos currículos dos mestrados e doutorados, visto que parcela dos mestrados $(56,6 \%, n=17)$ e dos doutorados $(76,6 \%$, $n=23)$ não tem essa exigência. Conclusão: Sugere-se a proposição de diretrizes brasileiras que impulsionem a formação didático-pedagógica do docente universitário.

\section{DESCRITORES}

Educação de Pós-Graduação em Enfermagem; Educação em Enfermagem; Educação Superior; Docentes.

\section{RESUMEN}

Objetivo: Caracterizar la formación didáctica pedagógica brindada en programas brasileños de posgrado stricto sensu en Enfermería. Método: Investigación descriptiva, documental, realizada a partir de los datos de 30 programas de posgrado que ofrecen curso de maestría académica y doctorado. Fueron recogidos los proyectos de curso y planes de estudios de las asignaturas relacionadas con la formación didáctica pedagógica, accedidos por vía Plataforma Sucupira o página web institucional. El análisis de las variables ocurrió por estadística descriptiva, mediante cálculos de frecuencia relativa y absoluta. Resultados: En cuanto a las líneas de investigación de los programas, se evidenció que el 17,4\% (n=20) tenían relación con la formación didáctica pedagógica, puesto que, en lo que se refiere a las áreas de concentración, el 9,4\% $(n=3)$ fueron las que contemplaron dicho enfoque y, con respecto a las asignaturas didácticas pedagógicas, se observó que se expresan de modo distinto en los currículos de las maestrías y doctorados, a la vista de que parte de las maestrías $(56,6 \%, n=17)$ y de los doctorados $(76,6 \%, n=23)$ no tienen dicha exigencia. Conclusión: Se sugiere la proposición de directrices brasileñas que impulsen la formación didáctica pedagógica del docente universitario.

\section{DESCRIPTORES}

Educación de Posgrado en Enfermería; Educación en Enfermería; Educación Superior; Docentes.

\section{REFERENCES}

1. Erdmann AL, Fernandes JD, Teixeira GA. Panorama da educação em enfermagem no Brasil: graduação e pós-graduação. Enferm Foco [Internet]. 2011 [citado 2017 jul. 25]; 2 Supl:89-93. Disponível em: http://www.scielo.br/pdf/reben/v66nspe/v66nspea14.pdf

2. Almeida Junior A, Sucupira N, Salgado C, Filho JB, Silva MR, Trigueiro D et al. Parecer CFE n. 977/65, aprovado em 3 dez. 1965 . Definição dos cursos de pós-graduação. Rev Bras Educ [Internet]. 2005 [citado 2017 maio 28];(30):162-73. Disponível em: http://www.scielo.br/ $\mathrm{pdf} / \mathrm{rbedu} / \mathrm{n} 30 / \mathrm{a} 14 \mathrm{n} 30 . \mathrm{pdf}$

3. Corrêa GT, Ribeiro VMB. Formação pedagógica na pós-graduação stricto sensu em saúde coletiva. Cien Saúde Coletivo [Internet]. 2013 [citado 2017 jul. 25];18(6):1647-56. Disponível em: http://www.scielo.br/pdf/csc/v18n6/16.pdf

4. Centro de Gestão e Estudos Estratégicos, Ciência Tecnologia e Inovação. Mestres e doutores 2015: estudos da demografia da base técnico-científica brasileira [Internet]. Brasília: CGEE; 2016. [citado 2017 maio 28]. Disponível em: https://www.cgee.org.br/ documents/10195/734063/MeD2015.pdf/d4686474-7a32-4bc9-91ae-eb5421e0a981

5. Scochi CGS, Munari DB, Gelbcke FL, Erdmann AL, Gutiérrez MGR, Rodrigues RAP. Pós-graduação Stricto Sensu em Enfermagem no Brasil: avanços e perspectivas. Rev Bras Enferm [Internet]. 2013 [citado 2017 maio 28];66(n.esp):80-9. Disponível em: http://www.scielo. br/scielo.php?script=sci_arttext\&pid=S0034-71672013000700011

6. Brasil. Ministério da Educação; Coordenação de Aperfeiçoamento de Pessoal de Nível Superior (CAPES), Diretoria de Avaliação. Documento de Área. Área da Enfermagem [Internet]. Brasília; 2013 [citado 2017 maio 28]. Disponível em: http://www.capes.gov.br/images/stories/ download/avaliacaotrienal/Docs_de_area/Enfermagem_doc_area_e_comiss\%C3\%A3o_att08deoutubro.pdf

7. Corrêa GT, Ribeiro VMB. A formação pedagógica no ensino superior e o papel da pós-graduação stricto sensu. Educ Pesqui [Internet]. 2013 [citado 2017 maio 28];39(2):319-34. Disponível em: http://www.scielo.br/pdf/ep/v39n2/a03v39n2.pdf

8. Martins FAS, Azevedo MTMD, Nonato SP. Docentes em formação e as significações produzidas em torno do ensino superior. Rev Docência Ensino Superior [Internet]. 2014 [citado 2017 jul. 25]; 4:137-66. Disponível em: https://seer.ufmg.br/index.php/rdes/article/ view/927/717 
9. Sampieri RH, Collado CF, Lucio MPB. Metodologia de pesquisa. $5^{\mathrm{a}}$ ed. Porto Alegre: Penso; 2013.

10. Marusic M, Mimica M, Mihanovic F, Jankovic S. Doctoral degree in health professions: professional needs and legal requirement. Acta Med Acad. 2013;42(1):61-70.

11. Brasil. Ministério da Educação; Coordenação de Aperfeiçoamento de Pessoal de Nível Superior (CAPES). Plano Nacional de Pós-Gradução (PNPG) 2011-2020 [Internet]. Brasília; 2010 [citado 2017 jul. 25]. Disponível em: https://www.capes.gov.br/images/stories/download/ PNPG_Miolo_V2.pdf

12. Menegaz JC, Backes VMS, Medina JL, Prado ML, Canever BP. Pedagogical practices of good nursing, medicine and dentistry professors from the students' perception. Texto Contexto Enferm [Internet]. 2015 [cited 2017 May 28];24(3):629-36. Available from: http://www. scielo.br/pdf/tce/v24n3/0104-0707-tce-24-03-00629.pdf

13. Queiroz FCBP, Queiroz JV, Vasconcelos NVC, Furukava M, Hékis HR, Pereira FAB. Transformações no ensino superior brasileiro: análise das instituições privadas de ensino superior no compasso com as políticas de Estado. Aval Pol Públ Educ [Internet]. 2013 [citado 2017 jul. 25];21(79):349-70. Disponível em: http://www.scielo.br/pdf/ensaio/v21n79/09.pdf

14. Dreifuerst KT, McNelis AM, Weaver MT, Broome ME, Draucker CB, Fedko AS. Exploring the pursuit of doctoral education by nurses seeking or intending to stay in faculty roles. J Prof Nurs. 2016;32(3):202-12.

15. Martínez LFP. Questões sociocientíficas na prática docente: ideologia, autonomia e formação de professores. São Paulo: Ed. UNESP; 2012.

16. Costa ACB, Chaves ECL, Terra FS, Monteiro LA. Perfil dos grupos de pesquisa de Enfermagem do Conselho Nacional de Desenvolvimento Científico e Tecnológico. Rev Rene [Internet]. 2014 [cited 2017 jun 07];15(3):471-9. Disponível em: http://200.129.29.202/index.php/ rene/article/view/3207/2466

17. Canever BP, Prado ML, Backes VMS, Lino MM. Characterization of research groups in nursing education in the state of São Paulo. Texto Contexto Enferm [Internet]. 2014 [cited 2017 May 28]; 23(1):21-8. Available from: http://www.scielo.br/scielo.php?script=sci_arttext\&pi $\mathrm{d}=$ S0104-07072014000100021

18. Backes VMS, Prado ML, Lino MM, Ferraz F, Reibnitz KS, Canever BP. Nursing Education Research Groups in Brazil. Rev Esc Enferm USP [Internet]. 2012 [cited 2017 May 28];46(2):436-42. Available from: http://www.scielo.br/scielo.php?pid=S0080$62342012000200023 \&$ script $=$ sci_arttext\&tlng=en

19. Shulman LS. Those who understand: knowledge growth in teaching. Educ Res. [Internet]. 1986 [cited 2017 June 10];15(2):4-14. Available from: https://pdfs.semanticscholar.org/f29d/a5d8c806102b060e7669f67b5f9a55d8f7c4.pdf

20. Menegaz JC, Backes VMS, Cunha AP, Francisco BS. O bom professor na área da saúde: uma revisão integrativa da literatura. Saúde Transform Soc [Internet]. 2013 [citado 2017 maio 28];4(4):92-9. Disponível em: http://pepsic.bvsalud.org/pdf/sts/v4n4/4n4a15.pdf

21. Brasil. Ministério da Educação; Coordenação de Aperfeiçoamento do Pessoal do Ensino Superior (CAPES). Portaria n. 76 , de 14 de abril de 2010. Aprova o novo Regulamento do Programa de Demanda Social constante do anexo a esta portaria. Diário Oficial da União, Brasília, 2010. Seção 1, p. 31.

22. Marin MJS, Tonhom SFR, Michelone APC, Higa EFR, Bernardo MCM, Tavares CMM. Projections and expectations of students enrolled in a teaching qualification in a technical health professional education course. Rev Esc Enferm USP [Internet]. 2013 [cited 2017 May 28];47(1):221-8. Available from: http://www.scielo.br/pdf/reeusp/v47n1/en_a28v47n1.pdf

23. Brasil. Ministério da Educação; Instituto Nacional de Estudos e Pesquisas Educacionais Anísio Teixeira (INEP), Diretoria de Estatísticas Educacionais. Censo da educação superior 2013: resumo técnico [Internet]. Brasília: INEP; 2015 [citado 2017 jun. 7]. Disponível em: http://download.inep.gov.br/download/superior/censo/2013/resumo_tecnico_censo_educacao_superior_2013.pdf 